\title{
A just and civilised humanity: An integrative model between reformed theology and the ideology of Pancasila
}

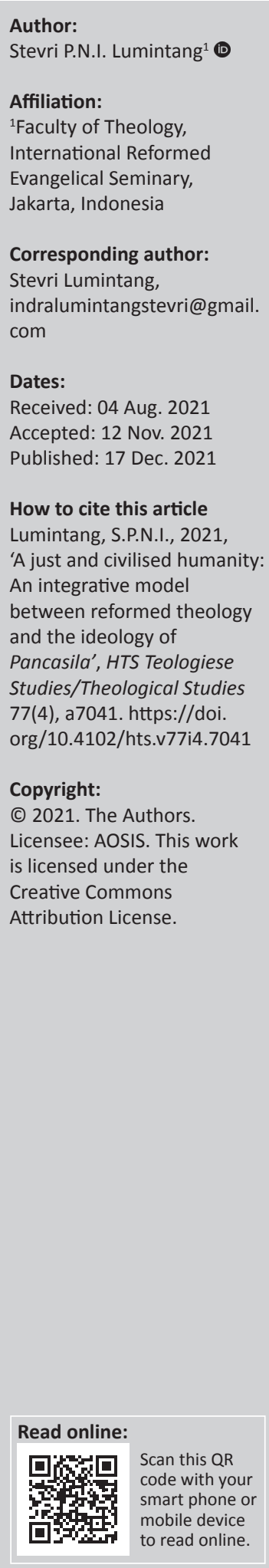

This study aimed to produce a model of integration between theology (reformed) and ideology (Pancasila) to realise a just and civilised humanity (second sila of Pancasila). This research is based on the paradigm of naturalism with qualitative methods and the approach applied is historical and integrative. The research results produced an integrative model between Reformed Theology and the ideology of Pancasila that rejects the understanding and practice of capitalism, religious fundamentalism, communism, and racism. This study pointed out that these four understandings and practices contradict the basic principles of a just and civilised humanity based on theological and ideological studies.

Contribution: This study produced four fundamental clues for all Indonesian citizens, especially Christians, namely the source, basis, pillars, and dual role as citizens and kingdoms of God in the fight for the formation of a just and civilised humanity.

Keywords: just; civilised humanity; ideology of Pancasila; reformed theology; integrative model.

\section{Introduction}

A just and civilised humanity is the second sila of Pancasila, the ideology of the Indonesian nation. It means internationalism and humanity. This concept is in accordance with the intention of the digger, namely Sukarno (2019). This just and civilised humanity deals with the structure and relationships between individuals in the society and nation (Banner 2008:3). The state guarantees the human rights of all citizens, but sadly Indonesia has not been free from crimes against humanity. The state guarantees the human rights of all citizens, but unfortunately Indonesia is not yet free from crimes against humanity, such as cases of kidnapping, torture, shooting, arson, including Munir-like cases against humanitarian heroes, and other cases committed by the military, many of which remain unsolved (Fernida 2020; Sulistia 2007). Sadly, human rights are still the subject of political debate, but crimes against humanity continue, and many are not solved (Yani 2010). Although the Jokowi-era government was better, it seemed to allow discrimination and religious freedom (Ananda 2020; Chairunnisa 2018a, 2018b; Lova 2020; Wilaya 2019), including the church bombings in Surabaya and the killings of people in Poso and Papua in 2021.

Considering the various incidents that involve violations of religious rights, it is a clear fact that Indonesia is still weak in implementing the second precept of Pancasila, namely Just and Civilised Humanity. Of course, the government cannot play its role without the support of all citizens. In addition to duty, Christian citizens receive the mandate of love (Mt 22:37-39), including fighting for humanity and religious freedom (Singgih 1998). In particular, reformed Christians believed that God had bestowed self-esteem on everyone, and that this should not be deprived of them (Calvin 2006; Vorster 2016). In fact, this mandate received less serious attention from Christians in general and reformed Christians in particular. Being indifferent to 'wrong and right' is not the attitude of a reformed Christian. At the same time, reformed Christians were accused of supporting authoritarianism and totalitarianism (Kuyper 2005 [1931]), which are the causes of capitalism (Fasenfest 2009:297; Weber 2006) and humanitarian violence (Alami 2006).

Humanitarian issues and their relationship to religious freedom have been widely discussed (Aminullah 2018; Daulay 2015; Intan 2019:57), as well as on the topic of the relationship between civilisation and religion (Chadwich 1986; Kardiman et al. 2020; Krejci 1982:29), especially the relationship between church and civilisation (Banner 2008; Kruip \& Reifeld 2007), including theology reformed and humanities relationship (Kovacs \& Barath 2009; Robinson 2020; Schindler 2008) and only Jeanne Heffernan Schindler (2008) wrote Christianity and Civil Society: Catholic and 
Neo-Calvinist Perspective and Abraham Kovacs and Levente Barath wrote Calvinism on Peripheries: Religion and Civil Society in Europe (2009) (Kovacs \& Barath 2009; Schindler 2008) Previous studies have not discussed specifically about civil society based on the perspective of reformed theology and its integration with the second precept of Pancasila, a just and civilised humanity. Therefore, this study has much significance in formulating a model of integration between theology (Reformed) and ideology (Pancasila) as a basis and reference to the dual role of Christians in realising a just and civilised humanitarian principle in Indonesia.

\section{Method}

According to Pancasila ideology and reformed theology, the study of civilised humanity involves two different disciplines, namely, ideology (politic) and theology (religion), which are disputed so far by fundamentalists and united by pluralists. This article was reviewed with a naturalism paradigm, with qualitative methods, and with integrative study approaches. This study is conducted in two stages. Firstly, exploring the concept of a just and civilised humanity, according to Pancasila ideology, and reformed theology based on historical-theological studies. Secondly, integrating both the ideas to find synthesis based on integrative methods. The integrative method synthesises knowledge and applicability of significant studies to practice, specifically integral dialectical synthesis. Dialectical synthesis is a method of reconciling dichotomous between two fields of study that are integrated, such as theology (religion) and ideology (politic) (Shirazi 2015).

\section{A just and civilised humanity in the ideology of Pancasila}

Before the proclamation of Indonesian independence on 17 August 1945, the Indonesian Independence Preparatory Agency for Investigation (Indonesia-BPUPKI) was formed on April 29. On 01 June 1945, Sukarno gave a speech to BPUPKI and proposed the ideology of Pancasila consisting of five precepts taken from the noble traditions of the Indonesian nation (Brata \& Wartha 2017). Thereafter, Pancasila (Pantja Sila) was established as the basis, philosophy, and source of Indonesian law on 08 August 1945. Furthermore, Pancasila is also referred to as the nation's soul and the basis for unifying the nation.

The second precept of Pancasila is a just and civilised society. During the speech about Pancasila, Sukarno called it internationalism or humanity. This second precept is preceded by the first precept, namely the One True God. That means the first sila illuminates the second sila and the other three silas (Madjid 2004). The value of humanity comes from God's law, the law of nature, and the social relationship between people. In particular, the right to life is a gift of God that should not be taken from every human being (Latif 2015).

According to Sukarno, the meaning of a just and civilised humanity or human life in a society is symbolised by a circular, square wrist chain that does not break. Round chains (females) and square chains (males) have a strong relationship. This chain also describes the relationship between nations and nations as a relationship between human beings. Man is homo socius, living in human society. Therefore, humanity is human nature, while humanity is the soul that distinguishes man from animals and feels the relationship between humans (Sukarno 2019).

Humanity is just and civilised humanity. Sukarno called it internationalism and humanity, which he summarised as socio nationalism. Therefore, Sukarno rejected capitalism, communism, religious fundamentalism, and ethnic racism, but universal nationalism, and did not hate other nations (Saksono 2007). Humanity is equality. Equal rights are natural rights, namely the right to life, freedom, and ownership based on the constitution of the nation, that is the Law of the Republic of Indonesia 1945, Article 27 (Sinal 2017).

\section{Reformed theocracy: The basic principles of just and civilised humanity}

Theocentrism is the central theme of reformed theology (Leith 1981:97), which explains God's spiritual and eternal government. Therefore, the kingdom of God transcends all the boundaries of this world (Marshal 1976:801). The concept of the kingdom of God concerning God as the Creator of all that exists, the King who reigns over all the world, and as the Redeemer who has come, is coming and will come in and through the person and work of Christ is the realisation of God's government in the world (Lumintang 2009:161). The government of God in Christ is through the church's role (Lumintang 2009) to realise the kingdom of God, which can be seen in the field of work, family, and school (Sproul 2019). This theocentric idea became the basis and reason for reformed Christians playing a role in the world (Greenway 2000:155). Therefore, the kingdom of God is the government of God which establishes righteousness and justice on earth as in heaven. Calvin emphasised the church's role in realising government (God's will) in the world, including personal freedom and regularity in a civil society community (Calvin n.d.).

Calvin, in his Institutes, discusses the concept of theocracy and civil government; the two are not contradictory (McNeill 1960:1485-1487). Therefore, he urged to be true to a civil society based on the sovereignty of God (Hinson-Hasty 2013:122-123). Calvin applied the corpus Christianum of Augustine in his ministry so that the city of Geneva became the centre and model of the reformed Christian world by applying the principles of the kingdom of God in society (De Jonge 2001:264-267). The only way the kingdom of God will be manifested in this world before Christ comes is by the way we live as the citizens of heaven and subjects of the King (Sproul 2019).

In particular, in his Institutes, Calvin discusses the concept of theocracy in relation to civil government. The spiritual and 
civil government are two different things (between mortal and eternal, accepting different duties from God), but the two are not contradictory (McNeill 1960:1485-1487). Therefore, he urged to be right towards the civilian government. For him, civil government is determined by God, based on God's sovereignty. The same is asserted by Abraham Kuyper, departing from God's sovereignty (divine government) over the whole world (cosmos), encompassing God's sovereignty in the country and society (Kuyper 2005 [1931]:79).

The formation of a civilised society is the will of God, which is a manifestation of spiritual government, which the church does. The reformed people also emphasised that the purpose of civil government is to create a society that can breathe, eat and drink, and enjoy happiness, and be involved in the realisation of public tranquillity or comfortable life. Thus, the involvement of Christians in the world of government (state) and society is part of the meaning of the kingdom of God. It is a calling, not only to be holy and obedient to the law of God but also the most basic and glorious, to be involved in all mortal human life (Kuyper 2005 [1931]:90).

Calvin's role in the city of Geneva provided the model of a just and civilised society governed by reformed theologian principles of human nature, human rights, and equality of all human beings before God, government, fellow, and self. A just and civilised society is a society built on the laws that protect every single person, not just a group of people. Indeed, the concept of Calvin theocracy was written in the context of 16th-century Christian society. However, the principles for a just and civilised humanity is still relevant to all people in all the countries, including in the context of a plural Indonesian society (religion, ethnicity, and culture).

\section{Understanding of just and civilised humanity in reformed theology}

The notion of the reformed theology, which is derived from the Bible, was formed by a reformed system that departed from the theocentric (kingdom of God) concept expressed in reality and life experience, including in social ethics and civil society, and humanity (Hinson-Hasty 2013:122-123). Civilised humanity discusses human rights (freedom), equality, and human dignity from the perspective of human nature. Civilised society and humanity deal with the right to life, religion, justice, opinion, involvement in government, education, employment, land, culture, and civil liberties (Meeter 2014:153). In this case, the nature of man is seen in relation to oneself, others, the country, and God. The government is obliged to protect its citizens materially and spiritually to ensure their civil liberties without interference from others.

There are four privileges of each civilian which should be guaranteed and protected by the (state) government. Firstly, the government is obliged to safeguard the rights of citizens, including organisations (citizen groups) such as churches, ecclesiastical foundations, educational institutions, and humanitarian institutions. Secondly, the government is obliged to maintain freedom of activities in churches, foundations, educational and humanitarian institutions, or other similar institutions. Thirdly, the state creates safe conditions that will enable citizens to work and obtain material welfare in accordance with human dignity. Fourthly, the state ensures the religious (spiritual) freedom of every citizen, including the freedom of public speaking (Meeter 2014:154-155).

Civilised humanity is also related to organisations in a society in associations of people for religious, cultural, social, and economic purposes. Usually, these organisations are nonprofit, non-governmental, and non-political parties. Civil society organisations such as social institutions, educational institutions organised by the community, rural associations, family unions, church institutions, and social and religious foundations were not established by the state (Vorster 2015:5).

A civilised society is defined as a totality of associations, relationships, and forms of cooperation between individuals in relation to the state (Banner 2008:3). Moreover, civil society relates to human values and moral attitudes based on human nature concerning norms and culture towards oneself, others, and the environment (Hutomo 2020). This concept has been given by God to men, namely loving God, others, and themselves (Mt 22:37-39). In other words, man must be fair to himself, to a neighbour, the country as a form of attitude towards God. That is the second principle of Pancasila, which is just and civilised humanity.

\section{Reformed theology: Theological foundations of a just and civilised humanity God's word}

There are similarities between discussing the rights of civilised citizens of civilised societies and human rights, and all related to theology and moral ethics. Christian theology and morality are derived from and based on the Bible. Herman Bavinck (2004:526) asserts that 'The unity of the human race as Scripture teaches is powerfully confirmed by all this - it is the presupposition of religion and morality'. Therefore, a decent attitude to others is a theological and ethical-moral attitude. This ethical-moral attitude is born from the theological understanding of human nature and is found only in the Bible.

In particular, there is no comprehensive explanation of a civilised society without reference to the Bible. The Bible is the word of God, including God's word of man to man. The final explanation of man includes human rights, and dignity cannot be obtained from any science of human origin, for it is impossible to find any solution within human limitations, except that it can only be obtained from the Creator, as it is written in the Bible. Tong asserts that the Bible guarantees absolute, complete, and perfect human rights. In the Bible, all human rights and the most important elements are listed (Tong 2013:6). 
The Bible is the source and standard of teaching about humans. Reformed theology strongly emphasises the principle of 'Bible only' (sola scriptura) as the only norm for faith and practical life, not only for understanding the Scripture but also for everything that it teaches, including human nature, human rights, and human dignity, including human beings in the context of civilised society (Horton 2011:139). The origin of man, the nature of man, the position of man among all creations of God and the Creator, the fall of man in sin, the law of loving God and others, all of these are found only in the Bible.

There is no description about a first-class, second-class or third-class man in the Bible. All men are equal in the unity of origin. The same God has created all men. All men sin, and all men need redemption. The mandate to love one another should be obeyed by all men. All of this is based on the unity of humankind (Bavinck 2004:526).

Ethical attitudes to others in accordance with Scripture have been governed by Scripture. Theological attitudes to God generate the ethical attitudes to others. The theological attitude to God involves loving God with totality and manifesting ethical-theological attitudes to others (Mt 22:37-39). A person who only loves God in Jesus Christ can be just and civilised to others and be pleasing to God. The concept of loving others is against killing, stealing, lying, and coveting others' properties (Ex 20:13-17). This is a just and civilised attitude from one person to another.

\section{God's design}

The Biblical-derived Christian view, formulated by early reformed theologians such as Zwingli and Calvin, states that the humans were an expressly designed creation of God (Erickson 2007:164-165). God designed and created man as a unique creature that is very special because God created it without matter (ex nihilo) (Warfield 2000:291). God formed man directly from the dust of the earth and breathed his breath of life so that man became a living being (Gn 2:7). This means that man, who is made of dust of the earth, does not have any reason to become arrogant. Moreover, because of the fact that human life originated from God, man should not kill one another.

All men are not copies of anything but rather created according to the ideas and designs of God. There is no difference except for gender differences, namely men and women. It means that all human beings are from the same source, namely the Creator and the same design (Grudem 1999:187). All men originated from the same source. Therefore, no human being is superior or more valuable than another. Likewise, the creation of man is based on the glory, wisdom, and goodness of God as Creator (Beeke \& Ferguson 1990:39). Man is the design and fruit of the glorious work of the glorious God, so it is judged 'very good' (Gn 1:31). That is why, if we treat others inappropriately, it is an insult to the Creator.

God's purpose is to create man for his glory (Isa 43:7, Eph 1:11-12, and 1 Cor 10:31). It explains that all men are valuable to God, that is, to the glory of God himself (Grudem 1999:188). The glory of God concerns his will, which is accomplished in and through man. In addition, God created humans in only two genders, male and female, with procreation (Lumintang 2020:61). Thus, the purpose of human creation and equality of all human beings is God's ideas and works, and the idea is the basis and reference of treating fellow human beings theologically.

\section{God's image}

God created humans in the image of God (Gn 1:27), while all other creations were made in their own image (Gn 8:19). Man is not the image of God but was created in the image of God. God's image is ontologically the whole excellence of human nature (Blocker 2009:73). Reformed theologians explain the meaning of 'image of God' as the default truth, true knowledge, holiness, eternity, and the human soul (thinking, feeling and willing). Bavinck interprets the image of God as the human soul, the human spiritual, the knowledge, the truth, the holiness, and the human conscience (Bavinck 2004:555-561). Man is superior to any other creation. Man is a glorious creature in the eyes of the Creator (Berkhof 1969:206). Therefore, man can communicate with God (Tong 2013:7). No other creatures can communicate with God. The communication between God and man is a theological communication according to the primary purpose of God in creating man, namely to commune with himself (Lumintang 2019:48).

The image of God also explains the noble role of man, namely to be God's proxy ruler in the world, that is the mandate to rule responsibly for all other creations (Gn 1:28). God has lifted the status of man higher than all other creations, even more so than angels. Thus, man is crowned with glory and respect (Ps 8:5). Although man is not God, man is valued by God with glory and respect, given power over all other creations. The image of God explains that man is a moral, spiritual, mental, and relational being (Grudem 1999:191-192). We are creatures who are morally accountable before God for our creation. We have not only physical bodies but also immaterial spirits. We can reason and think logically and learn what sets us apart from the animal world. We have a unique ability to relate to God and neighbours.

\section{God's free will}

As a unique creation, man has freedom in terms of knowledge, thinking, feeling, and will. This freedom comes from God's free will. Reformed theology acknowledges this, but after the fall in sin, man has lost God's free will to include all his desire and ability to do the right and good things of himself and cannot change himself for having died in sin (Rm 3:10-12, 5:6; 8:7, Jn 15:5, Eph 2:1; Col 2:13). The tendency of human will is to sin. Through believing and repentance, man's will becomes free in doing righteous and good things in the eyes of God and others (Col 1:13, Jn 8:34, Phil 4:13) (Beeke \& Ferguson 1990:57). 
Naturally, man has absolute freedom from God (Hall 2011:310), which makes him different from animals. Therefore, man should not be treated like an animal (Balke 2016:87). God naturally gives human freedom to be protected or guarded by the state (government) from the abuse of power by a stronger party (Meeter 2014:173). About certain people of the wrongful government, the reformed do not want to rebel against the government or violate the state's laws, even if oppressed because of their faith. John Calvin and Calvinism required people to be fully obedient to civil law enforcement because the noble motivation was obedience to God (Meeter 2014:155).

The government must safeguard the freedom of individuals in civil society through legislation. The freedom of individuals and civil society concerns social happiness (Kuyper 2005 [1931]:15-16). Indeed, the government must safeguard the freedom of individuals and civil society because the government bears the sword, namely, the authority for justice, war, and order. Civil society's freedom is in the form of protection, activities, and material welfare (Meeter 2014:153). The government has three dual obligations, including creating mutual respect, defending the weak, bearing individual burdens for the unity and maintenance of the state (Kuyper 2005 [1931]:97).

This freedom is not a kind of freedom according to human desires, but a freedom that has responsibility. Responsible freedom is an enslaved will and a spontaneous will (Meeter 2014:103). The enslaved will is the attitude of standing before God freely but dealing with others, and people should not do as they please. The obligations of every believer include supporting the government in safeguarding the freedom or sovereignty of the state, which in turn involves protecting the right of freedom of others.

\section{God's wrath}

Indeed, all men are important and noble beings in the eyes of God, as should be in the eyes of others. At the same time, the Bible reports that all men are sinful beings (Gn 3:6-8, $\mathrm{Rm} 3: 23)$. As a result of $\sin$, man is under the wrath of God (Rm 1:18, Col 3:6). Human sin, not only concerning actual sin, but sinful nature and the human condition become completely corrupted (total depravity) (Frame 2013:865). This suggests that man was spiritually powerless so that no one sought God (Rm 3:11), died in sin (Gn 2:17, Eph 2:1-3, Rm 5:15), no one was right, no one did good, and was inclined to do evil (Rm 3:10-12, 5:6, 7:8; Mt 15:19, Jm 1:14-15) (Beeke \& Ferguson 1990:47).

Although man has sinned and is entirely helpless, does not seek God, and does not do good to others in the eyes of God, the image of God in man is not lost, man does not become an animal or another creation, there is still enough likeness to God remaining in them that to murder another person is to attack the part of creation that most resemble God, to attack God himself. Man is still in God's image. God considers and reckons man (Ps 8:4; 144:3). God loves man, so he gives his only Son in exchange for sinners (Isa 423:4, Mk 10:45, Jn 3:16 and $1 \operatorname{Tim} 2: 6)$.

\section{God's love}

No one can love God, except God loves us by sending his only begotten Son as the way of atonement (1 Jn 4:10). God's love is eternal love ( $\mathrm{Jr}$ 31:3). Therefore, we must love God with eternal love (Eph 6:24). Loving God and others can only be done by believers. One who loves God also loves others (1 Jn 4:21). Loving one another is the second part of the 10 Commandments or decalogue (Ex 20:1-17), which is to honour thy parents, not to kill, commit adultery, steal, bear false witness against thy neighbour, and covet thy neighbour's house. The Lord Jesus Christ summarises these six attitudes to fellowmen in one commandment: to love one another as oneself, which is based on loving God (Mt 22:37-39) (Beeke \& Ferguson 1990:157). Loving one another by God's standards involves these practices: not killing, committing adultery, stealing, lying about others, and not coveting to have others.

In essence, civilised humanity is part of the theological and morality field that only departs from the Bible as a presupposition (Bavinck 2004). The Bible informs that all men are of value and equality because they were designed and created by God for his glorious purposes, created in a way that is in his own right, given responsible free will, all of whom are in the same condition as sinners and are in God's wrath, become objects of God's greatest gift (Jesus Christ), and experience God's love that impact on loving others. This is the absolute, complete, and perfect guarantee of human rights as the highest norm (Horton 2011). The theological foundation of a just and civilised humanity to others is described in Figure 1.

These seven theological foundations on human values are contrary to capitalism, religious fundamentalism, communism, and racism in a society and state. These four ideas deprive people of freedom, by not recognising the equality of rights and positions in the eyes of God and fellow human beings. These four concepts do not conform to the values of all human beings theologically, namely God's word, God's design, God's image, God's free will, God's wrath, God's love, and God's son. Thus, reformed theology is not a supporter but opposed to all forms of dehumanisation of capitalism, religious fundamentalism, communism, and racism.

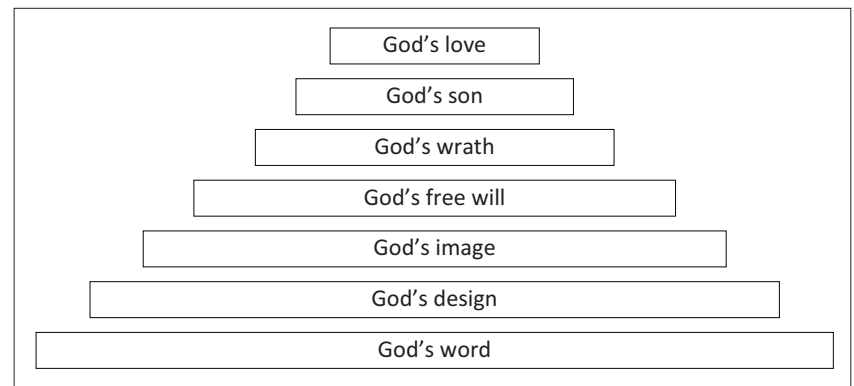

FIGURE 1: Seven theological foundations of humans' values. 


\section{Integration between reformed theology and the ideology of Pancasila}

Pancasila ideology and reformed theology are two concepts that are not unified but integrated with dialectical synthesis integration methods. Ideology and theology are two different areas of study and appear dichotomic, but both have similar and integrative values about humans, as revealed in Figure 2.

Figure 2 explains that Christians have double citizenship (dual citizenship), including citizens of the kingdom of God who lives according to God's will and citizens who live according to the state's rules and laws. Dual citizenship does not contain the opposition but is integrated into synthesis. Indonesian Christians, as citizens, recognise the nation's traditions as a source of ideology. As citizens of the kingdom of God (church), Christians recognise the Scriptures as a source of theology, Pancasila as the basis of national life, theology as the basis of religious life, the nation's constitution that regulates the rights and responsibilities as citizens, the Christian ethics that regulates the rights and responsibilities as citizens of the kingdom of God, and play a synergistic dual role as citizens and citizens of the kingdom of God.

By playing dual roles as citizens of Indonesia and members of the kingdom of God (church), all Christians become examples as good citizens who love and respect others despite their different religions, ethnicities and cultures. Thus, Christians will significantly contribute to realising a harmonious society and nation. As the example referred to above, being a good citizen is possible because Christians have two integrative (synergic) dual powers to play an integrative role as citizens and church members.

\section{Conclusion}

The study formulated an integrative model between Reformed Theology and the Ideology of Pancasila that rejects ideas and teachings about capitalism, totalitarianism, authoritarianism, religious fundamentalism, communism, and racism. In particular, reformed theology is not only contrary to these antihuman attitudes, but also provides a solid theological foundation for Christians to live and play a role in upholding a just and civilised humanity. The integration between theology (religion)

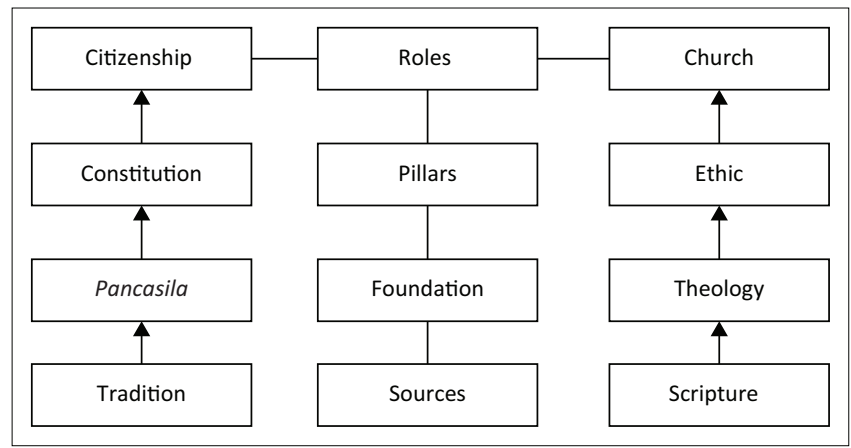

FIGURE 2: Integration: Double citizenship of the Christian. and the ideology of Pancasila (politics) produced a foundation and guidance for the necessity of the role of Christians. On this Pancasila earth, every Christian should hold the noble traditions of the nation and Scripture as the source of truth of people's lives, nationalities, and states. Pancasila and theology as the basis of humane attitudes; constitution (Undang-undang Dasar 1945) and Christian ethics as pillars of humanity; and the double role both as Indonesian citizens and church citizens (kingdom of God) who love each other, uphold the value of humanity, develop tolerance, not arbitrarily towards others, happy to do humanitarian activities and dare to defend truth and justice.

\section{Acknowledgements}

The author would like to thank Sekolah Tinggi Theologi Reformed Injili Internasional (STTRII) for supporting the study.

\section{Competing interests}

The author declares that he has no financial or personal relationships that may have inappropriately influenced him in writing this article.

\section{Author's contributions}

S.P.N.I.L. is the sole author of this research article.

\section{Ethical considerations}

This article followed all ethical standards for research without direct contact with human or animal subjects.

\section{Funding information}

This research received no specific grant from any funding agency in the public, commercial or not-for-profit sectors.

\section{Data availability}

Data sharing is not applicable to this article as no new data were created or analysed in this study.

\section{Disclaimer}

The views and opinions expressed in this article are those of the author and do not necessarily reflect the official policy or position of any affiliated agency of the author.

\section{References}

Alami, A.N., 2006, 'Kekerasan Ala Kapitalisme. Sebuah Telaah atas Buku violence and democratic society', Jurnal Penelitian Politik 3(1), 111-118.

Aminullah, A., 2018, 'Pendidikan Pancasila dan Agama', Jurnal Ilmiah Mandala Education 4(1), 149-155.

Ananda, P., 2020, 'Pembakaran Gereja di Sigi, PGI Himbau Masyarakat Tenang', Media Indonesia, viewed 28 November 2020, from https://mediaindonesia.com/politikdan-hukum/364735/pembakaran-gereja-di-sigi-pgi-imbau-masyarakat-tenang.

Balke, W., 2016, Pandangan Calvin mengenai Kebebasan, BPK Gunung Mulia, Jakara.

Banner, M., 2008, 'Christianity and civil society', in J.A. Coleman (ed.), Christian political ethics (eds.), pp. 3-21, Princeton University Press, Princeton, NJ.

Bavinck, H., 2004, Reformed dogmatics, Baker Academic, Grand Rapids, MI.

Beeke, J.R. \& Ferguson, S.B., 1999, Reformed confessions harmonized, Baker Books, Grand Rapids, MI. 
Berkhof, L., 1969, Systematic theology, The Benner of Truth Trust, Grand Rapids, MI.

Blocker, H., 2009, 'Calvin's theological anthropology', in S.W. Cheung (ed.), John Calvin and evangelical theology: Legacy and prospect, pp. 66-84, Westminster John Knox Press, Louisville, KY.

Brata, I.B. \& Wartha, I.B.N., 2017, Lahirnya Pancasila sebagai Pemersatu Bangsa Indonesia Fakultas Keguruan dan IImu Pendidikan Universitas Mahasaraswati, Denpasar.

Calvin, J., 2006, Institute of Christian religion, Westminster John Knox, London.

Calvin, J., n.d., Commentary on 2 Corinthians 2:12, viewed 21 July 2021, from https:// www.studylight.org/commentaries/eng/cal/2-corinthians-12.html.

Chadwich, O., 1986, 'Civilization and religion', Journal of the Royal Society of Arts 134(5356), 255-264.

Chairunnisa, N., 2018a, '40 Kasus Pelanggaran Kebebasan Beragama Dilakukan Aparat' Tempo, viewed 20 August 2018, from https://nasional.tempo.co/read/1118822/ setara-40-kasus-pelanggaran-kebebasan-beragama-dilakukan-aparat.

Chairunnisa, N., 2018b, ' 4 Kasus Pelanggaran Kebebasan Beragama di Era Jokowi' Tempo, viewed 23 October 2018, from https://nasional.tempo.co/ read/1138894/4-kasus-pelanggaran-kebebasan-beragama-di-era-jokowi.

Daulay, R., 2015, Agama dan Politik di Indonesia, BPK Gunung Mulia, Jakarta.

De Jonge, C., 2001, Apa itu Calvinisme?, BPK Gunung Mulia, Jakarta.

Erickson, M.J., 2007, Christian doctrine, Baker Academic, Grand Rapids, MI.

Fasenfest, D., 2009, 'Civil society of Calvinist theocracy', in M. Zafirovski (ed.), The destiny of modern societies, vol. 14, pp. 297-395, Brill, Leiden.

Fernida, I., 2020, '55 Tahun kejahatan terhadap Kemanusiaan 1965-66: Kebenaran dan Keadilan Belum Terpenuhi', Kontras Komisi Orang Hilang dan Korban Tindak Kekerasan, viewed 01 October 2020, from https://kontras.org/2020/10/01/55tahun-kejahatan-terhadap-kemanusiaan-1965-66-kebenaran-dan-keadilan-bagikorban-belum-terpenuhi/.

Frame, J.M., 2013, Systematic theology: An introduction to Christian belief, P\&R Publishing Company, Phillipsburg, NJ.

Greenway, R.S., 2000, 'Calvinism', in A.S. Moreau (ed.), Evangelical dictionary of world missions, pp. 155-560, Baker Books, Grand Rapids, MI

Grudem, W., 1999, Bible doctrine: Essential teachings of the Christian faith, Zondervan Grand Rapids, MI.

Hall, D.W., 2011, Calvin Di Ranah Publik: Demokrasi Liberal, Hak Asasi dan Kebebasan Sipil, Penerbit Momentum, Surabaya.

Hinson-Hasty, L., 2013, 'Calvinism on the Peripheries: Religion and civil society in Europe', Scottish Journal of Theology 66(1), 122-123. https://doi.org/10.1017/ S0036930611000445

Horton, M., 2011, For Calvinism, Zondervan, Grand Rapids, MI.

Hutomo, M.S., 2020, 'Kemanusiaan yang Adil dan Beradab, Makna dan Pengamalannya', Indomaritim, viewed 22 October 2020, from https://indomaritim.id/kemanusiaanyang-adil-dan-beradab-makna-dan-pengamalannya/.

Intan, B.F., 2019, 'Public religion and Pancasila-based state of Indonesia', Calvin Theological Journal 54, 57-89.

Kardiman, Y., Muchtar, A.S., Abdulkarim, A. \& Sapriya, 2020, 'Pancasila and civilized society', Advances in Social Science, Education and Humanities Research, vol. 418 pp. 380-385. Proceedings of the 2nd Annual Civic Education Conference (ACEC 2019), viewed 24 March 2020, from https://doi.org/10.2991/assehr.k.200320.072.

Kovacs, A. \& Barath, L., 2009, Calvinism on the peripheries: Religion and civil society in Europe, L'Harmattan, Budapest.

Krejci, J., 1982, 'Civilization and religion', Religion 12(1), 29-47. https://doi. org/10.1016/0048-721X(82)90014-8

Kruip, G. \& Reifeld, H., 2007, Church and civil society: The role of Christian churches in the emerging countries of Argentina, Mexico, Nigeria and South Africa, Konrad Adenauer Foundation, Berlin.
Kuyper, A., 2005 [1931], Lectures on Calvinism, Wm. B Eerdmans Publishing, Grand Rapids, MI.

Latif, Y., 2015, Revolusi Pancasila: Kembali Ker Rel Perjuangan Bangsa, Mizan, Yogyakarta.

Leith, J.H., 1981, Introduction to the reformed tradition, John Knox Press, Atlanta, GA.

Lova, C., 2020, 'Ibadah di Rumah Saat PSBB Dibubarkan Tetangga, Polisi Bilang Itu karena Salah Paham', Kompas, viewed 20 April 2020, from https://megapolitan. kompas.com/read/2020/04/20/10213331/ibadah-di-rumah-saat-psbbdibubarkan-tetangga-polisi-bilang-itu-karena?page=all.

Lumintang, S.I., 2009, Misiologia Kontemporer: Menuju Rekonstruksi Theologia Misi yang Seutuhnya, Departemen Multimedia YPPII, Batu.

Lumintang, S.I., 2019, Introduksi Theologia Sistematika: Sistem Berpikir LogisTheologis, Geneva Insani Indonesia, Jakarta.

Lumintang, S.I., 2020, Theologia Gender dan Seksualitas; LGBT, Geneva Insan Indonesia, Jakarta.

Madjid, N., 2004, Indonesia Kita, Penerbit PT Gramedia Pustaka Utama, Jakarta.

Marshal, I.H., 1976, 'Kingdom of God', in M.C. Tenney (ed.), The Zondervan pictoria encyclopedia of the Bible, vol. 3, pp. 801-802, Regency Reference Library, Grand Rapids, MI

McNeill, J.T., 1960, Calvin: Institutes of the Christian religion, vol. 2, pp. 1485-1487, Westminster Press, London.

Meeter, H.H., 2014, Pandangan-Pandangan Dasar Calvinisme, Penerbit Momentum, Surabaya.

Robinson, M., 2020, 'Reformed theology and humanities', in M. Allen \& S.R. Swain (eds.), The Oxford handbook of reformed theology, pp. 98-112, Oxford University Press, Oxford

Saksono, I., 2007, Pancasila Soekarno, Rumah Belajar Yabinkas, Yogyakarta.

Schindler, J.H., 2008, Christianity and civil society: Catholic and Neo-Calvinist perspective, Lexington Books, Minneapolis, MN.

Shirazi, B.A.K., 2015, 'Integrative research: Integral epistemology and integrative methodology', Integral Review 11(1), 17-27.

Sinal, M., 2017, Pancasila: Konsensus Negara-Bangsa Indonesia, Madani, Malang.

Singgih, E.G., 1998, 'Etika Kitab Suci dan Hak Asasi Manusia. Tinjauan Hermeneutik', Jurnal Filsafat dan Teologi 11(1), 104-121.

Sproul, R.C., 2019, What is the kingdom of God?, viewed 07 June 2019, from https:// www.ligonier.org/blog/what-is-kingdom-god/.

Sukarno, 2019, Filsafat Pancasila menurut Bung Karno, Media Pressindo, Yogyakarta.

Sulistia, T., 2007, 'Peran Internasional Criminal Court dan Kejahatan terhadap Kemanusiaan oleh Militer', Indonesia Journal of International Law 5(1), 16-42. https://doi.org/10.17304/ijil.vol5.1.146

Tong, S., 2013, Iman, Penderitaan dan Hak Asasi Manusia, Momentum, Surabaya.

Vorster, J.M., 2016, 'A reformed perspective on the concept of the "common good" and its relevance for social action in South Africa today', In die Skriflig 50(2), a2030. https://doi.org/10.4102/ids.v50i2.2030

Warfield, B.B., 2000, Calvin and Calvinism, Wm.B Eerdmans Publishing, Grand Rapids, MI.

Weber, M., 2006, Etika Protestan dan Spirit Kapitalisme, Pustaka Pelajar, Yogyakarta.

Wilaya, C., 2019, 'Setidaknya 200 Gereja Disegel dan Ditolak 10 Tahun Terakhir, apa Sebenarnya Dilakukan Pemerintah?', BBC News Indonesia, viewed 29 August 2019, from https://www.bbc.com/indonesia/indonesia-49494326.

Yani, Y.M., 2010, Hak Asasi Manusia dan Huhubungan Internasional, Universitas Padjajaran, Bandung, viewed 27 October 2018, from https://pustaka.unpad. ac.id/archives/50031. 